\title{
Anthelmintic and Other Pharmacological Activities of the Root Bark Extracts of Albizia anthelmintica Brongn
}

\author{
G. N. THOITHI ${ }^{*}$, N. MAINGI ${ }^{2}$, D. KARUME ${ }^{3}$, P. K. GATHUMBI ${ }^{2}$, \\ J. W. MWANGI ${ }^{3}$ AND I. O. KIBWAGE ${ }^{1}$
}

'Department of Pharmaceutical Chemistry, Faculty of Pharmacy, University of Nairobi, P.O. Box 1967600202, KNH, Nairobi, Kenya.

${ }^{2}$ Department of Veterinary Pathology, Microbiology and Parasitology, Faculty of Veterinary Medicine, University of Nairobi, P.O. Box 29053-00625, Kangemi, Nairobi, Kenya.

${ }^{3}$ Department of Pharmacology and Pharmacognosy, Faculty of Pharmacy, University of Nairobi, P.O. Box 19676-00202, KNH, Nairobi, Kenya.

The anthelmintic activity of water, methanol and chloroform extracts of the root bark of Albizia anthelmintica on strongyle-type sheep nematode eggs and larvae were examined in vitro. In addition, pharmacological tests were carried out on the water extract to confirm other ethnomedical uses of the plant. The water extract inhibited hatching of the nematode eggs as well as development of larvae. It caused larval mortality at moderately high doses. The methanol extract had no effect on the eggs and on the development of larvae, but had high activity against survival of the larvae. The chloroform extract was the least active of the three extracts and it had moderate effect on larval development and larval survival. In addition, the water extract caused contraction of the smooth muscle of the guinea pig and rabbit ileum and the rat uterus. The water extract had negative inotropic and chronotropic effects and contractile effects on guinea pig trachea. The results support the ethnomedical use of this plant as an anthelmintic and for prevention of hemorrhage after birth.

Key words: Albizia anthelmintica, anthelmintic activity, pharmacology

\section{INTRODUCTION}

Albizia anthelmintica Brongn. (Mimomaceae) is a tree or shrub 3-7 m, decidous; bark grey, smooth or deeply reticulate. Pinnae in 1-2 pairs, leaflets in 1-4 pairs, obliquely obovate or subcircular, apex mucronate, $10-40$ by $6-35 \mathrm{~mm}$ usually glabrous. Flowers usually on leafless twigs, white or yellow, staminal tube not or hardly exserted. Fruit glossy pale brown, $7-18$ by $1.5-2.8 \mathrm{~cm}$, usually glabrous. Pod papery, straw-coloured, 3-5 seeded. The plant is common on dry bushland on lava or along seasonal rivers, less often in wooded or bushed grassland or woodland; rarely in evergreen coastal bushland $[1,2]$.

A decoction of the stem bark or root is used as an anthelmintic, mainly for tapeworm [2-13]. The plant is also used as a purgative, as a sexual stimulant for women, to prevent pregnancy and haemorrhage after birth, for treating malaria, syphilis, gonorrhea, rheumatism, amoebic dysentry and fever [3-11,14-16]. Traditional practitioners in Kenya caution that inhaling of the ground powder causes severe headaches, breathing problems [17] and an overdose may cause death $[3-5,17]$.

The stem barks water extract of $A$. anthelmintica from South Africa has been shown to have activity against the earthworm [18], while that from Sudan was active against the cestode Hymenolepis diminuta in rats $[19,20]$, the liver fluke Fasciola gigantica in goats [21] and the blood fluke Schistosoma mansoni [22]. The leaf water extract from Sudan was weakly active against Caenorhabditis elegans [23]. The stem bark water extract and powder from Ethiopia showed antimitotic activity in rats and taenicidal activity in adult human [24]. The methanol extract of the bark from Tanzania had weak activity against Neisseria gonorrhea, but no activity against Escherichia coli, Staphylococcus aureus, Shigella [9] and the brine shrimp (Artemia salina) [25]. None of the extracts (methanol, dichloromethane or petroleum ether) tested had any activity against Plasmodium falciparum [26]. Methanol extracts caused relaxation of the smooth muscle of rat uterus and contraction of the guinea pig ileum and the trachea [8].

Compounds which have been isolated from the plant include amino acid derivatives [27, 28], 
histamine and related imidazole compounds [7], the saponins musennin and deglucomusennin $[7,11,12]$ and echinocystic acid saponins [10].

In Kenya, $A$. anthelmintica is one of the most popular plants for treatment of worms in animals and man. However, few studies have been carried out on the plant from Kenya to support its use. Studies from other countries have shown that the stem bark and leaf water extracts have anthelmintic activity [18-23]. This paper reports the in vitro activity of $A$. anthelmintica root bark extracts of different polarity against various stages of nematode worms. In addition, pharmacological tests were carried out to confirm other ethnomedical uses of the plant.

\section{MATERIALS AND METHODS}

\section{Plant collection, identification and preparation}

Ethnobotanical studies with communities in Yatta (Machakos district), Mwea (Thika district) and Narok town (Narok district) identified Albizia anthelmintica root bark as a commonly used anthelmintic in livestock and humans. The root bark was collected from Yatta, Machakos district, Kenya in June 2000. It was identified at the Department of Botany, University of Nairobi. Voucher specimens were deposited at the same place and at the Faculty of Pharmacy, University of Nairobi. Dried and ground plant material $(50 \mathrm{~g})$ was boiled for $30 \mathrm{~min}$, filtered through filter paper, freeze dried and stored at $-20^{\circ} \mathrm{C}$.

\section{In vitro anthelmintic activity tests}

Isolation of eggs and preparation of test solutions. The eggs used for in vitro anthelmintic activity tests were obtained using a modification of the method described by Le Jambre [29]. Faecal samples were collected from the rectum of a number of sheep with no history of recent deworming, crushed and soaked in clean tap water. The suspension was passed through 212,56 and $28 \mu \mathrm{m}$ sieves to remove debris, the eggs being retained on the $28 \mu \mathrm{m}$ sieve. The residue was mixed with saturated saline solution and the suspension was allowed to settle. Faecal debris, being denser than the saline solution, settled on the bottom of the beaker, while the Strongyle eggs being lighter, floated on the surface. A plastic petri-dish was placed on the surface of the suspension, so that the Strongyle eggs could adhere on to the bottom of the petri-dish. These were recovered by washing off with distilled water. An estimate of the concentration of the eggs was determined and the egg suspension was diluted in distilled water to about 10 eggs per $20 \mu \mathrm{l}$. Sixty mg of the water and methanol extracts were each dissolved in $2 \mathrm{ml}$ distilled water to form the stock solutions having a concentration of $30,000 \mu \mathrm{g} / \mathrm{ml}$. The chloroform extract $(60 \mathrm{mg})$ was first dissolved in a minimum amount of Tween 80 (about $30 \mu \mathrm{l}$ ) and then made to $2 \mathrm{ml}$ with water.

Egg Hatch Assay (EHA): Serial dilutions were carried out to give solutions containing 10,000 , $5,000,2,500,1,250,625,312.5$ and $156.25 \mu \mathrm{g} / \mathrm{ml}$ of the extracts. Control tubes containing distilled water and $30 \mu \mathrm{I}$ of Tween 80 (which was also serially diluted) were included in the set up. About $80 \mu \mathrm{l}$ of Strongyle eggs solution were added into each tube and incubated at $27^{\circ} \mathrm{C}$ for $48 \mathrm{~h}$. The number of eggs, which had not hatched and number of hatched larvae were counted and percent hatching calculated.

Larval Survival Assay (Larval Mortality assay) (LMA): After determination of the EHA, the plates were incubated for a further $48 \mathrm{~h}$. The number of live worms and dead worms was determined and percent death calculated.

Larval Development Assay (LDA): Eggs were incubated in absence of the extracts for $48 \mathrm{~h}$ for hatching to take place. The larvae were then inoculated with dose levels of $10,000,5,000$, $2,500,1,250,625,312.5$ and $156.25 \mu \mathrm{g} / \mathrm{ml}$ of the different extracts and incubated for 7 days. Control tubes containing distilled water and Tween 80 were included in the set-up. The number of larvae that did not develop from larval stage one $\left(L_{l}\right)$ to larval stage three $\left(L_{3}\right)$ was determined.

Thiabendazole at concentrations ranging from $0.02(0.1 \mu \mathrm{M})$ to $2.7 \mu \mathrm{g} / \mathrm{ml}(13 \mu \mathrm{M})$ was used to test the sensitivity of the nematode eggs to benzimidazoles (positive control), while the solvents were used as the negative controls. All tests were carried out in duplicate.

\section{General pharmacological tests}

The pharmacological tests were done as described by Vogel et al. [30]. 
Isolated Rabbit Ileum: A rabbit was killed after starving for $24 \mathrm{~h}$ and a piece of ileum $(2.5 \mathrm{~cm})$ were removed and mounted in a $20 \mathrm{ml}$ organ bath containing Krebs Henseleit solution [31], aerated with $95 \% \mathrm{O}_{2}$ and $5 \% \mathrm{CO}_{2}$ and maintained at $37^{\circ} \mathrm{C}$. After equilibration for about $30 \mathrm{~min}$, doses of the water extract ranging from 0.25 to 5.0 $\mathrm{mg} / \mathrm{ml}$ bath concentration were introduced and a $2 \mathrm{~min}$ tissue-drug contact time was allowed during which the contraction of the ileum was recorded on a kymograph. The tissue was rinsed and allowed to rest for $3 \mathrm{~min}$ before repeating the cycle.

Isolated Guinea Pig Ileum: The conditions and procedure used were the same as those for rabbit ileum and doses of the water extract of $A$. anthelmintica ranging from 0.005 to $0.2 \mathrm{mg} / \mathrm{ml}$ bath concentrations were investigated.

Isolated Guinea Pig Trachea: A guinea pig was sacrificed and the trachea isolated and placed in Krebs Henseleit solution. About $3 \mathrm{~cm}$ of the trachea was mounted on a U-shaped capillary tube on one side and the other opening was connected to a graduated $0.1 \mathrm{ml}$ pipette. The capillary terminal was connected to a $5 \mathrm{ml}$ syringe containing Krebs Henseleit solution. The tissue was immersed in the solution in a double walled $20 \mathrm{ml}$ organ bath aerated with $95 \% \mathrm{O}_{2}$ and $5 \%$ $\mathrm{CO}_{2}$ and maintained at $37^{\circ} \mathrm{C}$ and it was allowed to equilibrate. Doses of the extract ranging from 0.05 to $0.4 \mathrm{mg} / \mathrm{ml}$ bath concentrations were investigated. Changes in fluid volume inside the pipette were noted after every minute for $8 \mathrm{~min}$. The tissue was rinsed and the cycle repeated with a different concentration of the extract.

Isolated Rat Uterus: A uterus from a young virgin rat was sensitised by subcutaneous administration of estradiol $(0.1 \mathrm{mg} / \mathrm{kg}$ body weight $) 48 \mathrm{~h}$ before the animal was sacrificed. A piece of the uterus was separated from the fat and connective tissue and set up in a $20 \mathrm{ml}$ organ bath containing De Jalon Ringer solution maintained at $37^{\circ} \mathrm{C}$. The tissue was aerated with $95 \% \mathrm{O}_{2}$ and $5 \% \mathrm{CO}_{2}$. After equilibration for about $30 \mathrm{~min}$ the plant extract was added and allowed a contact time of 30-60 sec. The tissue was washed twice with De
Jalon Ringer solution and allowed to rest for 3 min before changing the extract concentration.

Isolated Rabbit Heart: A rabbit was sacrificed and the heart was removed with about $1 \mathrm{~cm}$ of the aorta intact. The heart was placed in a Petri dish containing Locke solution and squeezed gently to remove the blood. The extraneous fatty tissue was removed and then the heart was attached through the aorta to the base of the Langendoff apparatus. The heart was coated with liquid paraffin to prevent drying. The perfusion liquid from a cannula was introduced through the aorta and its rate adjusted to achieve a satisfactory heart beat. The perfusion liquid was aerated with $95 \% \mathrm{O}_{2}$ and $5 \% \mathrm{CO}_{2}$ and maintained at $37^{\circ} \mathrm{C}$. The apex of the heart was hooked and attached to a pulley and to a BioScience Oscillograph 400 recorder. The plant extract was introduced by injecting it just above the cannula.

\section{RESULTS AND DISCUSSION}

Table 1 shows the $\mathrm{ED}_{50}$ of the three $A$. anthelmintica root bark extracts on the Egg Hatch Assay, Larval Development Assay and Larval Mortality Assay. The water extract inhibited hatching of eggs as well as development of larvae from $L_{1}$ to $L_{3}$. It showed moderate activity in terms of larval mortality. This sequential activity on both the eggs and larval stages of the worm's life cycle is similar to that of the benzimidazole anthelmintics which are active against the eggs, larvae and adult stages of nematode worms [32]. The methanol extract has no effect on the eggs and on the development of larvae, but has high activity against survival of the larvae. The chloroform extract was the least active showing moderate effect on larval development and larvae survival, but no activity on the eggs. None of the extracts was as active as thiabendazole, a benzimidazole anthelmintic used as a positive control in the tests. The results support the work of other researchers who reported that the water extracts of the stem bark and the leaves have anthelmintic activity [18-24]. There are no previous reports of the efficacy of methanol or chloroform extracts. 
Table 1. Anthelmintic activity $\left(\mathrm{ED}_{50}\right)$ of the water, methanol and chloroform extracts of Albizia anthelmintica root bark

\begin{tabular}{lccc}
\hline \multirow{2}{*}{ Drug } & \multicolumn{3}{c}{ ED $_{\mathbf{5 0}}$ in $\mu \mathrm{g} / \mathbf{m l} \mathbf{( 9 5} \%$ Confidence Limits) } \\
\cline { 2 - 3 } & Egg IIatch Assay & Larval Development Assay & Larval Mortality Assay \\
\hline Water exuact & 144.1 & 65.2 & 312.4 \\
& $(89.3-191.0)$ & $(21.1-100.2)$ & $(258.4-375.4)$ \\
Methanol extract & 920.0 & $1,143.3$ & 11.8 \\
& $(1,029.2-1,621.8)$ & $(748.1-1,608.7)$ & $(6.5-104.0)$ \\
Chloroform extract & $2,400.0$ & 208.0 & 479.8 \\
& $(a)$ & $(126.6-287.6)$ & $(370.5-663.1)$ \\
Thiabendazole & 0.095 & 0.067 & $\mathrm{ND}$ \\
\hline
\end{tabular}

ND: Not determined

Pharmacological work was carried out on the water extract since it had good anthelmintic activity combined with low toxicity to experimental animals [33]. At a bath concentration above $0.25 \mathrm{mg} / \mathrm{ml}$, A anthelmintica water extract caused contractions of isolated rabbit ileum. At a concentration of $5 \mathrm{mg} / \mathrm{ml}$ the extract caused contraction similar in magnitude to that caused by acetylcholine at $0.05 \mu \mathrm{g} / \mathrm{ml}$. After washing, the tissue was subjected to $0.5 \mu \mathrm{g} / \mathrm{ml}$ adrenaline and this caused relaxation. The contractions caused by the extract were not abolished by use of $0.5 \mu \mathrm{g} / \mathrm{ml}$ adrenaline coadministered with the extract (Figure 1).

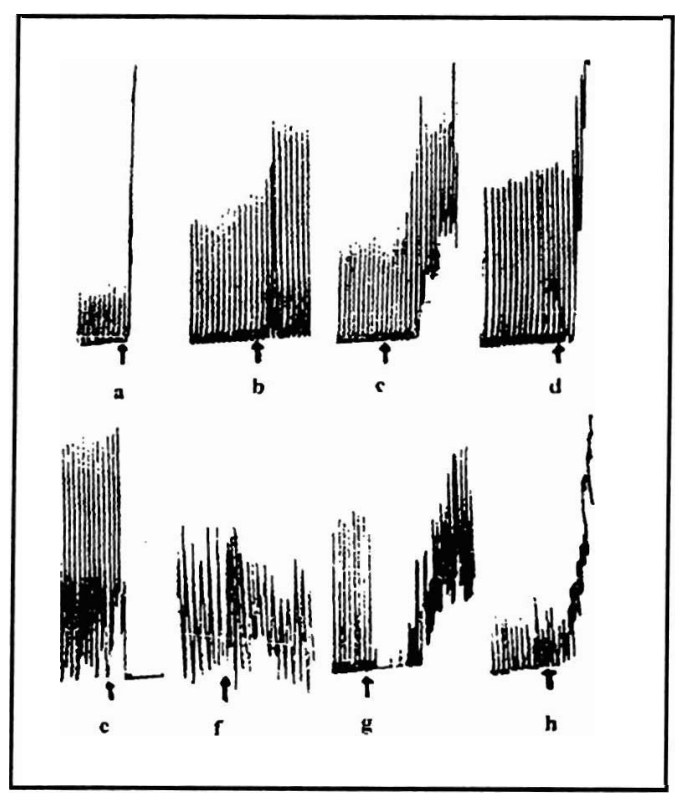

Figure 1: The contractive effect of the water extract of Albizia anthelmintica root bark on rabbit ileum. A: 0.05 $\mu \mathrm{g} / \mathrm{ml}$ acetylcholine, b: $0.25 \mathrm{mg} / \mathrm{ml}$ extract, c: $0.5 \mathrm{mg} / \mathrm{ml}$ extract, $\mathrm{d}: 5 \mathrm{mg} / \mathrm{ml}$ extract, e: $0.5 \mu \mathrm{g} / \mathrm{ml}$ adrenaline and $\mathrm{h}$ : $5 \mathrm{mg} / \mathrm{ml}$ extract and $0.5 \mu \mathrm{g} / \mathrm{ml}$ adrenaline.
Figure 2 shows that the contraction of the guinea pig ileum plotted against the logarithm of the bath concentration of the water extract gave a sigmoid curve. The extract produced contraction of guinea pig ileum at bath concentrations above 0.005 $\mathrm{mg} / \mathrm{ml}$ and the maximal response was reached at $0.1 \mathrm{mg} / \mathrm{ml}$. The $\mathrm{EC}_{50}$ was $0.04 \mathrm{mg} / \mathrm{ml}$. The guinea pig ileum was more sensitive than that of the rabbit.

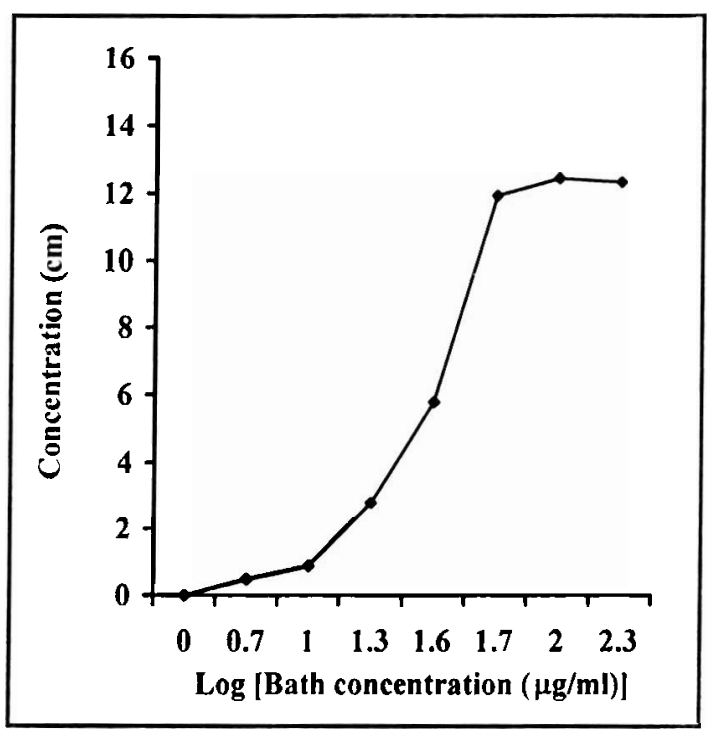

Figure 2. Logarithm dose response curve showing the contractile effect of the water extract of Albizia anthelmintica root bark on guinea pig ileum

The water extract caused contractions of the guinea pig trachea in bath concentrations of 0.05 to $0.4 \mathrm{mg} / \mathrm{ml}$ (Figure 3). At concentrations of 0.2 $\mathrm{mg} / \mathrm{ml}$ and above, there was no further increase in contraction, but increasing the concentration to $0.4 \mathrm{mg} / \mathrm{ml}$ shortened the onset of the maximal effect. 


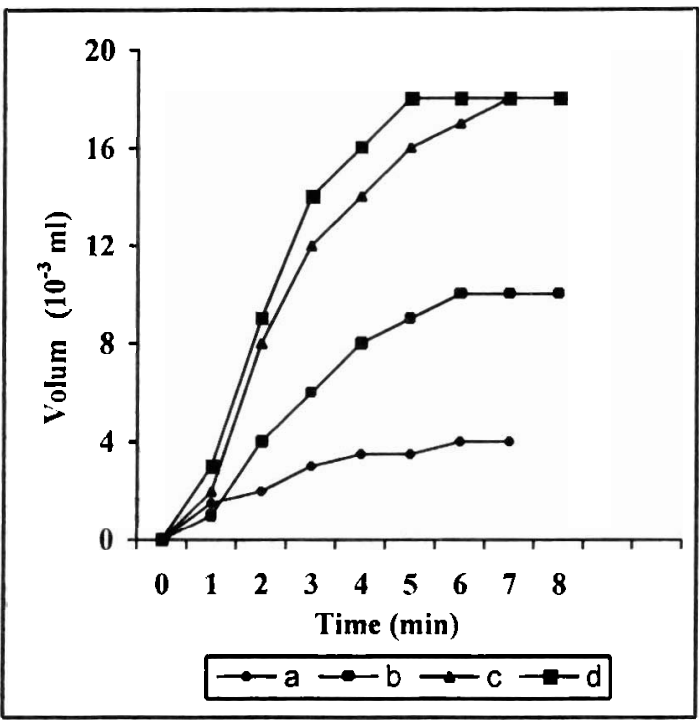

Figure 3. The contractile effect of the water extract of Albizia anthelmintica root bark on guinea pig trachea. a: $0.05 \mathrm{mg} / \mathrm{ml}$, b: $0.1 \mathrm{mg} / \mathrm{ml}$, c: $0.2 \mathrm{mg} / \mathrm{ml}$ and $\mathrm{d}: 0.4$ $\mathrm{mg} / \mathrm{ml}$.

Figure 4 shows that the water extract caused contraction of a sensitized rat uterus at $1.0 \mathrm{mg} / \mathrm{ml}$ which were about four times weaker than those caused by $0.005 \mathrm{I}$.U./ml of oxytocin.

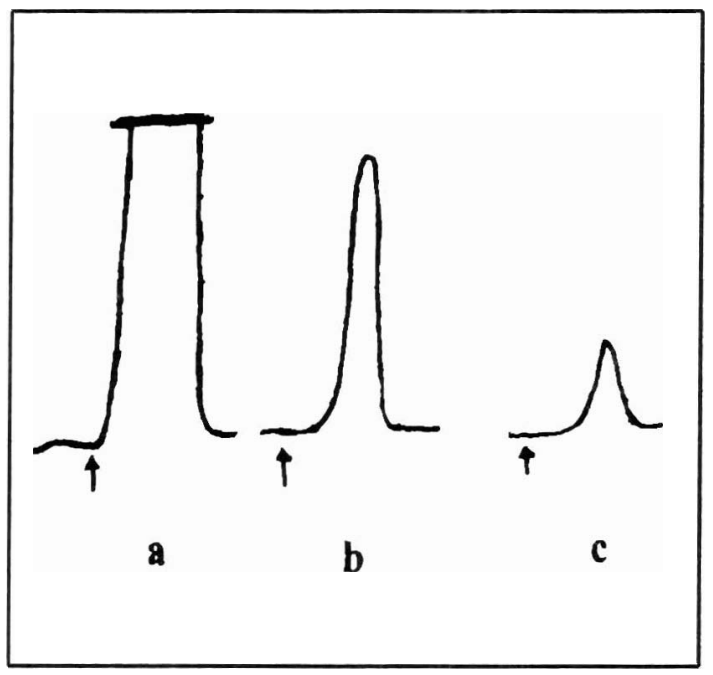

Figure 4: The effect of the water extract of Albizia anthelmintica root bark on isolated rat uterus. a: 0.005 I.U. $/ \mathrm{ml}$ oxytocin, b: $1 \mathrm{mg} / \mathrm{ml}$ extract and c: $0.5 \mathrm{mg} / \mathrm{ml}$ extract

The contractility effects of different concentrations of the water extract on rabbit heart are shown on figure 5 . The water extract $(0.5$ $\mathrm{mg} / \mathrm{ml}$ ) caused decrease in the contractility of the rabbit heart (negative inotropic effect).

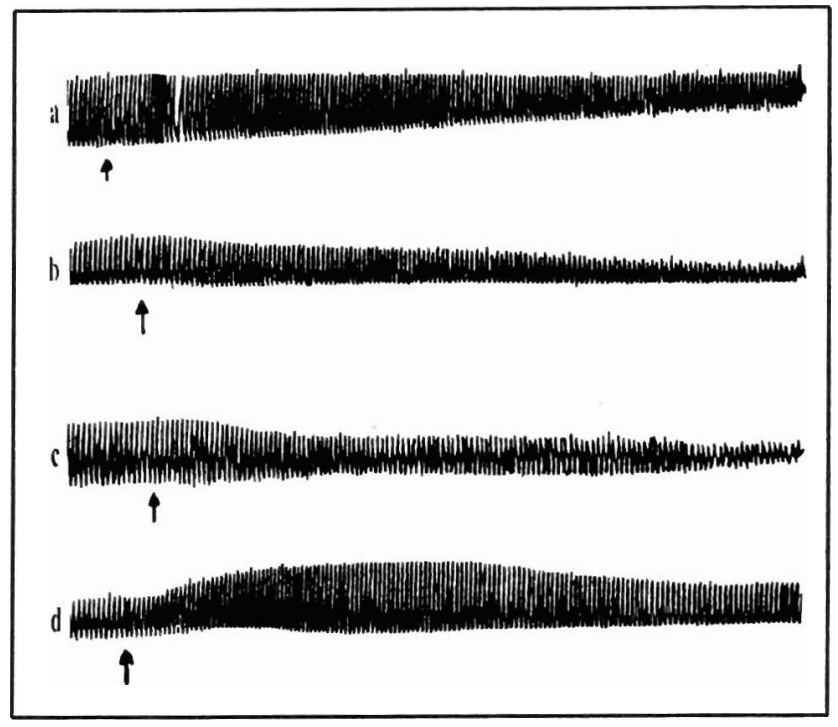

Figure 5. The offect of the water extract of Albizia anthelmintica root bark on isolated rabbit heart. a: 0.5 $\mathrm{mg} / \mathrm{ml}$, b: $1 \mathrm{mg} / \mathrm{ml}$ extract, c: $2.5 \mathrm{mg} / \mathrm{ml}$ extract and $\mathrm{d}$ : $0.05 \mu \mathrm{g} / \mathrm{ml}$ adrenaline.

The maximum effect was achieved at a concentration of $1 \mathrm{mg} / \mathrm{ml}$ and increasing the concentration to $2.5 \mathrm{mg} / \mathrm{ml}$ caused no further effect. At concentrations 0.5 and $1.0 \mathrm{mg} / \mathrm{ml}$ the extract had no effect on the heart rate, but at 2.5 $\mathrm{mg} / \mathrm{ml}$ the heart rate was slowed (negative chronotropic effect) to $80 \%$ of the normal rate followed by organ death. In contrast, adrenaline had positive inotropic and chronotropic effects.

\section{CONCLUSION}

This work reports for the first time the anthelmintic activity of the water, methanol and chloroform extracts and the pharmacological activity of the water extract of $A$. anthelmintica root bark. The polar extracts (water and methanol) had good anthelmintic effect, but the chloroform extract had moderate effect. In addition, the water extract caused contraction of the smooth muscle of the guinea pig and rabbit ileum and the rat uterus. The results support the ethnomedical use of this plant as an anthelmintic and for prevention of hemorrhage after birth. In addition to the anthelmintic effect, the contractile action of the water extract may propel the worms out of the gastrointestinal tract. The fatal effects of the plant may be due to its effects on the heart and the contractile effects on the respiratory system. 


\section{ACKNOWLEDGEMENT}

The authors thank the communities of Yatta, Mwea and Narok for ethnomedical information, Dr. R. Chadha for technical assistance and The Rockefeller Foundation Africa Career Awards, (Grant No. 2001 AR 006) for financial support.

\section{REFERENCES}

[1] H.J. Beentje, Kenya Trees Shrubs and Lianas. National Museums of Kenya, Nairobi. 1994, p 270.

[2] F.N. Gachathi, Kikuyu Botanical Dictionary of Plant Names and Uses. GTZ, Nairobi. 1989, p 66-67.

3] G.O. Kokwaro, Medicinal Plants of East Africa. East Africa Literature Bureau, Nairobi. 1976, p 127.

[4] I. Hedberg, O. Hedberg, P.J. Madati, K.E. Mshigeni, E.N. Mshiu and G. Samuelsson, J. Ethnopharmacol. 9 (1983) 105-127.

[5] G. Samuelsson, M.H. Farah, P. Claeson, M. Hago, M. Thulin, O. Hedberg, A.M. Warfa, A.O. Hassan, A.H. Elmi, A.D. Abdurahman, A.S. Elmi, Y.A. Abdi and M.H. Alin, J. Ethnopharmacol. 37 (1992) 93-112.

[6] T. Johns, E.B. Mhoro, P. Sanaya and E.K. Kimanani, Econ. Bot. 48 (1994) 90-95.

[7] G. Mazzanti, G.F. Erspamer, Y. Mugne and D. Piccineli, Fitoterapia. 54 (1983) 275-280.

[8] H.S. Khalid, A.K. Bashir, A.H. Mohmed and M.B. Alil, Int. J. Phamacog. 34 (1996) 226-228.

[9] S.C. Chhabra and F.C. Uiso, Fitoterapia. 62 (1991) 499-503.

[10] G. Carpani, F. Orsini, M. Sisti, L. Verotta, Phytochemistry. 28 (1989) 863-866.

[11] R. Tschesche and F.J. Kammerer, J. Liebigs Ann. Chem. (1969) 183-193.
[12] R. Tscheche and D. Forstmann, Chem. Ber. 90 (1957) 2383.

[13] A. El-Hamidi, Planta Med. 18 (1970) 278.

[14] Bally, Bull Misc Information Roy. Bot. Gard. 11(1937) 10-26.

[15] M. Merker, Die Masai. Second Edition, Dietrich Reimer, Berlin. 1910. p 196.

[16] J.M. Watt and M.G. Breyer-Brandwijk, The Medicinal and Poisonous Plants of Southern and Eastern Africa. Second Edition. E. S. Livingstone Ltd., London. 1962.

[17] G. N. Thoithi, J. W. Mwangi, I. O. Kibwage, P. K. Gathumbi and N. Maingi, Personal communication with Herbalists in Yatta, Machakos district and Mwea, Thika district, Kenya. 2001.

[18] J.M. Watt, Arch. Int. Pharmacodyn. Ther. 33 (1927) 267.

[19] M. Galal, A. Bashir, A. Salih and S. Adam, Vet. Hum. Toxicol. 33 (1991) 537539.

[20] M. Galal, A.K. Bashir., A.M. Salih and S.E.I. Adam, J. Ethnopharmacol. 31 (1991) 333-337.

[21] W.S. Koko, M. Galal and H.S. Khalid, J. Ethnopharmacol.7I (2000) 247-252.

[22] S.H. Elsheikh, A.K. Bashir, S.M. Suluman and M.E. Wassila, Int. J. Crude Drug Res. 28 (1990) 241-245.

[23] A. M. Ibrahim, Phytotherapy Res. 6 (1992) 155-157.

[24] B. Desta, J. Ethnopharmacol. 45 (1995) 27-33.

[25] A.Y. Massele and C.M. Nshimo, E. Afr. Med. J. 72 (1995) 661-663. L.B. Mwasumbi, L.S. Kinabo, Planta 
Med., 56 (1990) 368-370

[27] G.J. Krauss and H. Reinbothe, Biochem. Physiol. Pflanz., 161 (1970) 243.

[28] R. Tschesche and F.J. Kammerer and G. Wulff, Z. Naturforch. Ser. B. 21 (1966) 596.

[29] L.F. Le Jambre, Vet. Parasitol. 2 (1976) 385-391.

[30] G.H. Vogel and W.H. Vogel, Drug Discovery and Evaluation; Pharmacological Assays. Sprunger-Verlag BerlinHeidelberg, New York. 1997 p 80-82, 184-185, 496-497.
[31] K.R. Brain and T.D. Turner, The Practical Evaluation of Pharmaceuticals. John Wright and Sons Ltd., Dorchester.1975, p 112-156.

[32] C.A. Behm and C. Bryant, The Mode of Action of some Modern Anthelmintics. In: Resistance in Nematodes to Anthelmintics Drugs. Eds. N. Anderson and P. Walter. CSIRO Division of Animal Health, Australian Wool Corporation Technical Report. 1983.

[33] G.N. Thoithi, P.K. Gathumbi, N. Maingi, J.W. Mwangi and I.O. Kibwage, The Acute and Sub-acute Toxicity of the Water Extract of Albizia anthelmintica Root Bark. In Preparation. 